Article

\title{
Can Agriculture Balance Its Energy Consumption and Continue to Produce Food? A Framework for Assessing Energy Neutrality Applied to French Agriculture
}

\author{
Souhil Harchaoui *(1) and Petros Chatzimpiros * \\ Laboratoire Interdisciplinaire des Énergies de Demain (LIED), Université Paris Diderot, 75013 Paris, France \\ * Correspondence: sharchaoui@yahoo.fr (S.H.); petros.chatzimpiros@univ-paris-diderot.fr (P.C.)
}

Received: 30 September 2018; Accepted: 4 December 2018; Published: 6 December 2018

\begin{abstract}
In the context of energy transition, agriculture is facing a double challenge, which is to reduce its fossil fuel dependency and provide-in addition to food-bioenergy to society for substitution to fossil fuels. The feasibility of this challenge depends on whether agriculture can achieve energy neutrality, meaning to balance its consumption of external energy by energy recovery from internal sources. Livestock feed is a major determinant in this balance. We use France as a demonstration case of the changing role of feed in the long-term agricultural energy metabolism and the challenge of reaching energy neutrality. Results show that current agriculture is structurally energy deficient to such an extent that its functional energy requirements almost equal its final produce. The energy recovery potential from crop residues and manure could at best cover the primary biomass equivalent of the external energy inputs to agriculture. Only a suppression of feed from cropland combined with very high energy recovery from agricultural residues could allow achieving energy neutrality and making agriculture a net energy source to society.
\end{abstract}

Keywords: sustainability; agriculture; energy balance; energy neutrality; crop residues; manure; feed

\section{Introduction}

Agriculture used to be a major source of energy to preindustrial societies and practically the only source of mechanical power before the industrial revolution [1]. The challenge of energy transition calls for re-acknowledging agriculture as an energy source able to provide, in addition to food, bioenergy to society for substitution to fossil fuels. However, current agriculture heavily relies on fossil fuels itself [2-4] and, thereby, it is far from being a renewable energy system. From the late 1960s to date, the role of energy in agri-food systems and in particular the reliance on fossil fuels has been examined and quantified with a growing research interest [5-10]. The analysis of the energy metabolism of agricultural systems can provide insights on structural energy deficits or surpluses and on the complex relationships between energy inputs and productivity $[4,11,12]$. Agricultural transitions entail structural changes in the energy metabolism and feeding capacity of agriculture and highlight the relevance of industrial ecology approaches in prospective agricultural modelling. Recently, the fourfold increase in the farm surplus i.e., the feeding capacity of agriculture, during agricultural industrialization was demonstrated for France, highlighting the role of improved resource conversion efficiencies and of the disruption of self-fueling in this increase [4]. Self-fueling is the sum of internal biomass invested as an energy input in agricultural production and got almost fully replaced in less than three decades by external energy inputs. The reliance on external inputs lifts internal productivity constraints and, in the case of fossil fuels, built a high agricultural productivity on exhaustible and carbon-cycle disturbing inputs. 
Several studies have addressed environmental externalities of agriculture relating to resource use and the carbon cycle and have discussed options to reduce or neutralize these externalities [13-18]. However, the challenge for agriculture to neutralize its energy dependence on external inputs through energy recovery from internal sources is given very little scrutiny in literature. Energy neutrality for agriculture equates to produce as much energy from internal sources as it consumes from external sources in support of food production. Energy neutrality is a pledge of food security against fossil fuels price volatility and a potential future scarcity and a prerequisite for agriculture to be a net energy source to society. Only by reaching energy neutrality can agriculture contribute bioenergy to the energy transition. Despite the critical relevance of this issue [19-21], no studies have gone further than assessing prospective energy self-sufficiency for isolated crop [22,23] or livestock systems [24]. Livestock holds a central role in agricultural metabolism, and its energy role fundamentally changed during industrialization from a vector of labor to a producer of meat and milk [25]. Globally, today livestock provides $21 \%$ of the dietary energy intake to humans [26] and accounts for more than $35 \%$ of total cereal grains consumption and for $75 \%$ of total agricultural land use [27].

This paper builds on recent insights on agricultural transitions in historical perspective and pursues a double objective regarding prospective energy modeling. First, it highlights the changing role of livestock feed in the long-term agricultural energy metabolism. Second, it constructs a full and consistent energy balance between food surplus, agricultural residues and the functional energy requirements of agriculture. It considers energy recovery from crop residues and manure and elaborates the concept of energy neutrality to discuss the opportunities and limitations of agriculture to maintain its farm surplus while neutralizing its energy dependency on external energy sources. It uses French agriculture as a reference demonstration case of a system with high energy efficiency, high food production, and export capacity, for which achieving energy-neutrality seems to be extremely challenging.

\section{Materials and Methods}

\subsection{Energy Analysis of Food Systems}

Figure 1 provides the conceptual framework for analyzing energy flows and balances in agriculture including vegetal and livestock production systems. Net production is the sum of extracted vegetal biomass plus livestock production minus total feed. Total feed includes all feedstuff produced domestically or imported from abroad (essentially soybean cake in the case of France), thus it corrects domestic net production for feed trade.

Preindustrial agriculture was energy neutral. Virtually all the energy invested as an input to the production system was sourced by self-fueling which was the sum of food for farmers and feed for working animals. Farm surplus was the final agricultural produce once the system had fulfilled its functional energy requirements [4]. Self-fueling got progressively replaced by external energy inputs used for traction machines, irrigation, greenhouses, livestock facilities, and synthetic fertilizers. At any given time, total energy invested in agriculture is the sum of self-fueling and external energy inputs. The share of self-fueling in this total accounts for the energy self-sufficiency of agriculture.

Today, self-fueling is close to zero. Farm surplus includes biomass for food and biomass allocated to first generation biofuels production. Independently on whether biofuels are returned to agriculture as an input, their production constitutes a factor of energy neutrality but competes with food. Agriculture may potentially recover energy from crop residues and manure [28] to produce energy neutrality without competition with food. Energy recovery from agricultural residues differs from self-fueling in that it does not necessarily return to agriculture. It corresponds to the production of second-generation biofuels.

By comparing the energy recovery potential to the primary biomass equivalent of the external energy inputs, we derive a positive or negative net energy balance accounting respectively for the structural energy surpluses or deficits of agriculture. A positive balance implies that the 
farm surplus is structurally independent from external energy subsidies and that agriculture can, in addition to farm surplus, provide bioenergy to society. In contrast, a negative balance implies that agricultural production is structurally energy deficient and that in absence of external energy subsidies, farm surplus cannot be sustained. A reduction in farm surplus proportional to the energy shortfall is inevitable unless if energy efficiency is increased. Higher energy efficiency means lower dissipation in the production system. It can be achieved either through higher conversion efficiency between final and primary energy inputs or through cuts in the amount of the biomass used as feed.

The main feed categories are grain and by-products (including cereals and oil crops produced domestically or imported), annual fodder and grasses. Feed consumption depends on the type and size of livestock populations and on the feed to food conversion efficiency. Here we assess the effect of grain feed and annual fodder suppression and of energy recovery from crop residues and manure on the net energy balance of agriculture. We use France as a reference case in four scenarios. The results are put in common perspective with feed use and the energy invested in agricultural production in historical perspective $[4,29,30]$.

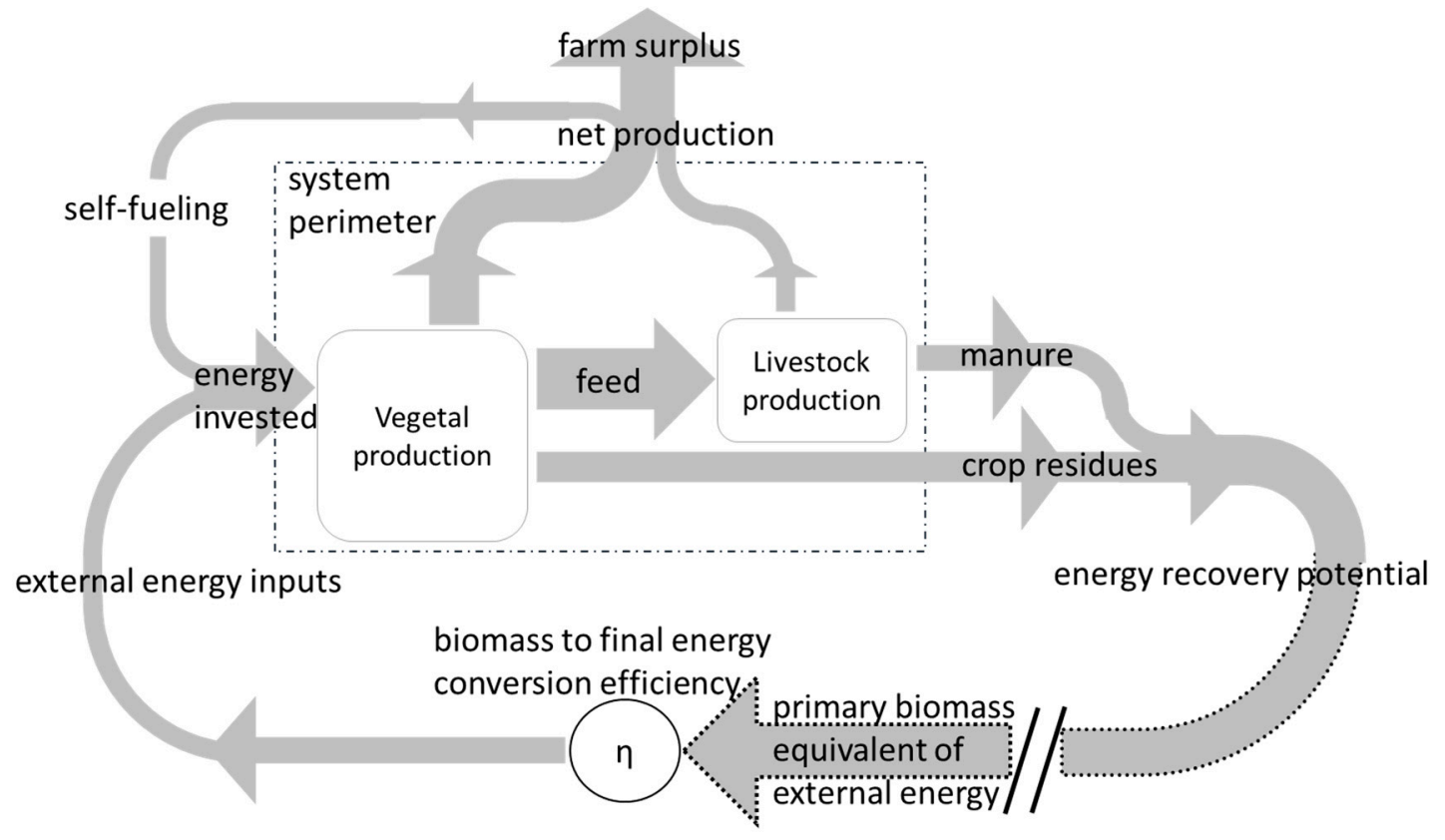

Figure 1. Generic representation of the energy flows in agriculture.

\subsection{Primary Biomass Equivalent of External Energy Inputs}

The primary biomass equivalent of external energy inputs is calculated by considering the type of final energy use and the associated conversion efficiency $(\eta)$ between primary and final energy. The energy use in agriculture is dividable among mechanical, heat, and the energy embodied in fertilizers and other resource inputs.

The conversion of biomass to mechanical energy can be either done directly by draft animals or by motors through a two-step process. The first step is the conversion of biomass to fuel which depends on the conversion pathway [31,32] of the biomass feedstock and is about $30 \%[31,33,34]$ for a final oil-equivalent fuel (see Supplementary Materials for detailed calculation). The second step is the combustion of fuel to mechanical power, with a typical efficiency of 40-50\% [35,36]. Accordingly, the energy conversion efficiency of biomass to power through motors is about $12-15 \%$ which is close to the efficiency range of draft animals over a full cycle including energy requirements for both maintenance and work $[4,37]$. As a result, the conversion efficiency fundamentally depends on the primary energy source rather than on the converter (Figure 2). Of course, the power level of motors is 
a multiple of that of draft animals, but through a number of draft animals equal to the power level gap the same cumulative power can be obtained with the same energy conversion efficiency.

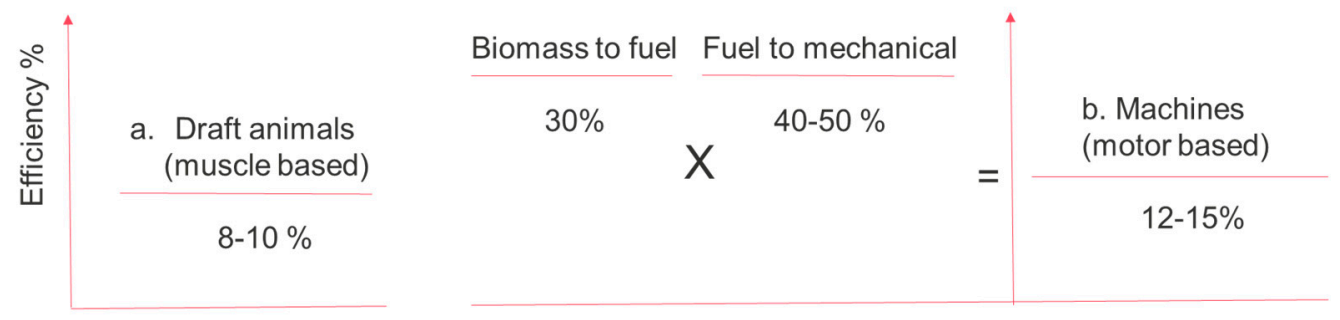

Figure 2. Energy conversion efficiency of biomass to mechanical work by draft animals and machines.

The conversion efficiency of biomass to heat is considered at 90\% [38] and for the energy embodied in fertilizers at $45 \%$, by considering a mix of heat and biomass gasification in the Haber Bosch process for ammonia synthesis, currently overwhelmingly reliant on natural gas as a hydrogen feedstock and on high pressure and temperature conditions for achieving high yields [39].

Table 1 shows, on the one hand, the share of fossil fuels and the distribution of total final energy use in current agriculture among mechanical, heat, and the energy embodied in resource inputs and, on the other hand, the calculated conversion efficiency and associated primary biomass equivalent per use $[4,30]$. Machines fuel is dominated by tractors and combine harvester-threshers. Livestock facilities include heating, lighting, and ventilation. The 'other' category includes irrigation and the energy embodied in pesticides and imported feed.

Table 1. Final energy consumption in French agriculture per use in 2013, clustered among mechanical power, heat, and energy embodied in fertilizers (N, P, K)

\begin{tabular}{cccccc}
\hline Use & $\begin{array}{c}\text { Current Fossil } \\
\text { Fuel (\%) }\end{array}$ & $\begin{array}{c}\text { Final } \\
\text { Energy PJ }\end{array}$ & Energy Type & $\begin{array}{c}\text { Conversion } \\
\text { Efficiency } \boldsymbol{\eta} \text { (\%) }\end{array}$ & $\begin{array}{c}\text { Primary Biomass } \\
\text { Equivalent PJ }\end{array}$ \\
\hline Fertilizers & 100 & 142 & 0.5 gas/0.5 heat & 45 & 316 \\
Machines fuel & 100 & 103 & mechanical & 30 & 343 \\
Greenhouses & 81 & 17 & 0.5 mechanical/0.5 heat & 45 & 38 \\
LV facilities & 35 & 29 & 0.5 mechanical/0.5 heat & 45 & 54 \\
Other & 75 & 15 & mechanical & 30 & 811 \\
\hline Total & 91 & 306 & & 38 & \\
\hline
\end{tabular}

\subsection{Energy Recovery Potential and the Net Energy Balance of Agriculture}

The net energy balance is calculated for four scenarios using the year 2013 as a reference date for the current energy metabolism of agriculture. The four scenarios quantify how much the farm surplus would change if agriculture were to reach energy neutrality. In the context of growing food demand, the share of first-generation biofuels in farm surplus is likely to phase out for the sake of food security, especially given the ongoing loss trend of agricultural land. Indeed, total agricultural area in France decreased by 17\% since 1961 [26], mainly driven by urbanization [40]. Given this trend, a stabilization or increase in agricultural area is doubtful as well as it is unadvisable because it would most likely compete with forestland with risks for soil carbon destorage, erosion, and loss of ecosystem services and biodiversity [41]. Accordingly, the four energy neutrality scenarios are constructed for both current total agricultural area and farm surplus fully put aside for food production.

The scenarios are constructed on two drivers. On the one hand, the energy recovery from manure and crop residues with a medium and high variant and, on the other hand, the suppression of feed grain and annual fodder (Table 2). Feed reduction brings down livestock production, energy consumption in livestock facilities (for heating, ventilation, and operating milking parlors), and available manure. The livestock productivity and manure excretion depend on feed (Feed) and its energy conversion efficiency (ECE) to food which varies among livestock production (i) and 
rations compositions. ECE $E_{i}$ and Feed $\mathrm{i}_{\mathrm{i}}$ are calculated for the year 2013 based on Harchaoui and Chatzimpiros [29]. The suppression of grain feed and annual fodder mainly affects monogastric animals and milk production respectively, which have the highest $\mathrm{ECE}_{\mathrm{i}}$. The suppression lowers the ECE of these sectors according to the new rations composition [42] as well as the aggregate livestock ECE (Table 2). In all scenarios, the energy share of milk and meat from cattle is kept as today at respectively $70 \%$ and 30\%. The energy consumption in livestock facilities equals total livestock production times an energy intensity coefficient taken at $0.42 \mathrm{~J}$ of primary biomass per $\mathrm{J}$ of livestock production [4] (Table 2).

Table 2. Description of the four scenarios.

\begin{tabular}{|c|c|c|c|c|c|}
\hline & Scenarios & S1a & S1b & S2a & S2b \\
\hline Drivers & $\begin{array}{l}\text { Energy recovery rate }\left(R_{c}\right) \text { from crop residues \% } \\
\text { Grain feed \& annual fodder }\end{array}$ & $\begin{array}{c}30 \\
\text { current }\end{array}$ & $\begin{array}{c}30 \\
\text { suppression }\end{array}$ & $\begin{array}{l}70 \\
\text { current }\end{array}$ & $\begin{array}{c}70 \\
\text { suppression }\end{array}$ \\
\hline \multicolumn{6}{|c|}{ Variables depending on livestock feed } \\
\hline & Energy conversion efficiency $\left(\mathrm{ECE}_{\mathrm{i}}\right) \%$ & \multicolumn{4}{|c|}{$\mathrm{S} 1 \mathrm{~b}, \mathrm{~S} 2 \mathrm{~b}$ (feed suppression) } \\
\hline & Milk & \multicolumn{2}{|c|}{16.5} & \multicolumn{2}{|c|}{8} \\
\hline & Beef & \multicolumn{2}{|c|}{2.5} & \multicolumn{2}{|c|}{2} \\
\hline & Pork & \multicolumn{2}{|c|}{17.7} & \multicolumn{2}{|c|}{ NA } \\
\hline & Chicken \& Eggs & \multicolumn{2}{|c|}{19.3} & \multicolumn{2}{|c|}{ NA } \\
\hline & Sheep \& Goat & \multicolumn{2}{|c|}{2} & \multicolumn{2}{|c|}{1.8} \\
\hline & Aggregate ECE & \multicolumn{2}{|c|}{8.5} & \multicolumn{2}{|c|}{4.6} \\
\hline & Aggregate time spent in confinement $\%$ & \multicolumn{2}{|c|}{48.7} & \multicolumn{2}{|c|}{40} \\
\hline & Livestock production (LV) & \multicolumn{4}{|c|}{$\sum$ Feed $_{i} \times E C E_{i}$} \\
\hline & Energy consumption in livestock facilities & \\
\hline & Energy recovery from manure & \multicolumn{4}{|c|}{$M E \times \sum_{i}$ Feed $_{i} \times\left(1-E C E_{i}\right) \times t_{i}$} \\
\hline \multicolumn{6}{|c|}{ Energy costs for agricultural residues recovery } \\
\hline & Crop residues & \multicolumn{4}{|c|}{$0.17 \times R_{c} \times \sum_{j}\left(\frac{1-H I_{j}}{H I_{j}}\right) \times$ harvest $_{j}$} \\
\hline & Manure & \multicolumn{4}{|c|}{$0.32 \times M E \times \sum_{i}^{1}$ Feed $_{i} \times\left(1-E C E_{i}\right) \times t_{i}$} \\
\hline
\end{tabular}

The energy recovery potential from crop residues, mainly straw, is calculated based on the harvest index of crops (HI), i.e., the ratio of crop yield to the crop's total aboveground biomass, derived from literature [43]. Total energy in crop residues is the sum of the harvested biomass per crop (harvest $j_{j}$ ) times the share of residues $\left(1-\mathrm{HI}_{\mathrm{j}}\right) / \mathrm{HI}_{\mathrm{j}}$ in total aboveground biomass. From this total, we consider a medium and high recovery rate $\left(\mathrm{R}_{\mathrm{c}}\right)$ of $30 \%$ and $70 \%$ respectively. Both rates are very ambitious compared to the almost zero energy recovery today. The medium and high rates inversely relate to high and medium soil carbon conservation objectives [33,44].

Concerning manure, only the manure produced in confinement is recoverable in contrast to excretions during grazing [45]. The average time spent in confinement per animal $\left(t_{i}\right)$ is $45 \%$ for cattle, $10 \%$ for sheep and goat, and $90 \%$ for pig and poultry $[33,45,46]$. The difference between feed intake and livestock production is metabolic heat losses and manure energy [34]. We consider that manure energy (ME) is $15 \%$ to $40 \%$ of this difference to reflect variability specific to livestock and to feedstuff digestibility [34,47-49]. Manure produced in confinement is assumed to be fully recovered, which is an optimistic assumption.

The recovery of agricultural residues has an energy cost associated to logistic and technical steps, such as compressing, picking up, pre-treating, and transporting the materials to the digester [50]. Accounting for this energy cost in details is out of the scope of the paper. Here, we provide a simple approximation by assuming a consumption of respectively $0.17 \mathrm{~J}$ of primary biomass per $\mathrm{J}$ recovered from crop residues and $0.32 \mathrm{~J}$ per $\mathrm{J}$ recovered from manure. These consumption factors are derived from Table 1 by respectively assuming an increase in machine fuel proportional to the non-economic yield of crops (1-HI) and a doubling in the energy consumption in livestock facilities representing energy costs for collection, transportation, preparation, and pumping of manure. These energy recovery costs 
are within the range (low end) of a detailed review analysis of various biogas systems in Sweden [51]. Table 2 presents the main data and calculation formulas in the four scenarios.

\section{Results}

\subsection{Feed Use and the Energy Budget of Agriculture}

Figure 3 shows the energy metabolism of agriculture over time by putting in common perspective the overwhelming amount of feed for livestock production (meat, milk, and eggs), the farm surplus of agriculture, the energy invested in the production system from internal and external sources and the primary biomass equivalent of the external energy inputs. Total feed currently represents more than $60 \%$ of all extracted vegetal biomass in France. The right panel of Figure 3 highlights that about half of total feed is supplied by grain and annual fodder crops. Grain feed accounts for more than $35 \%$ of total grain production in France [26].

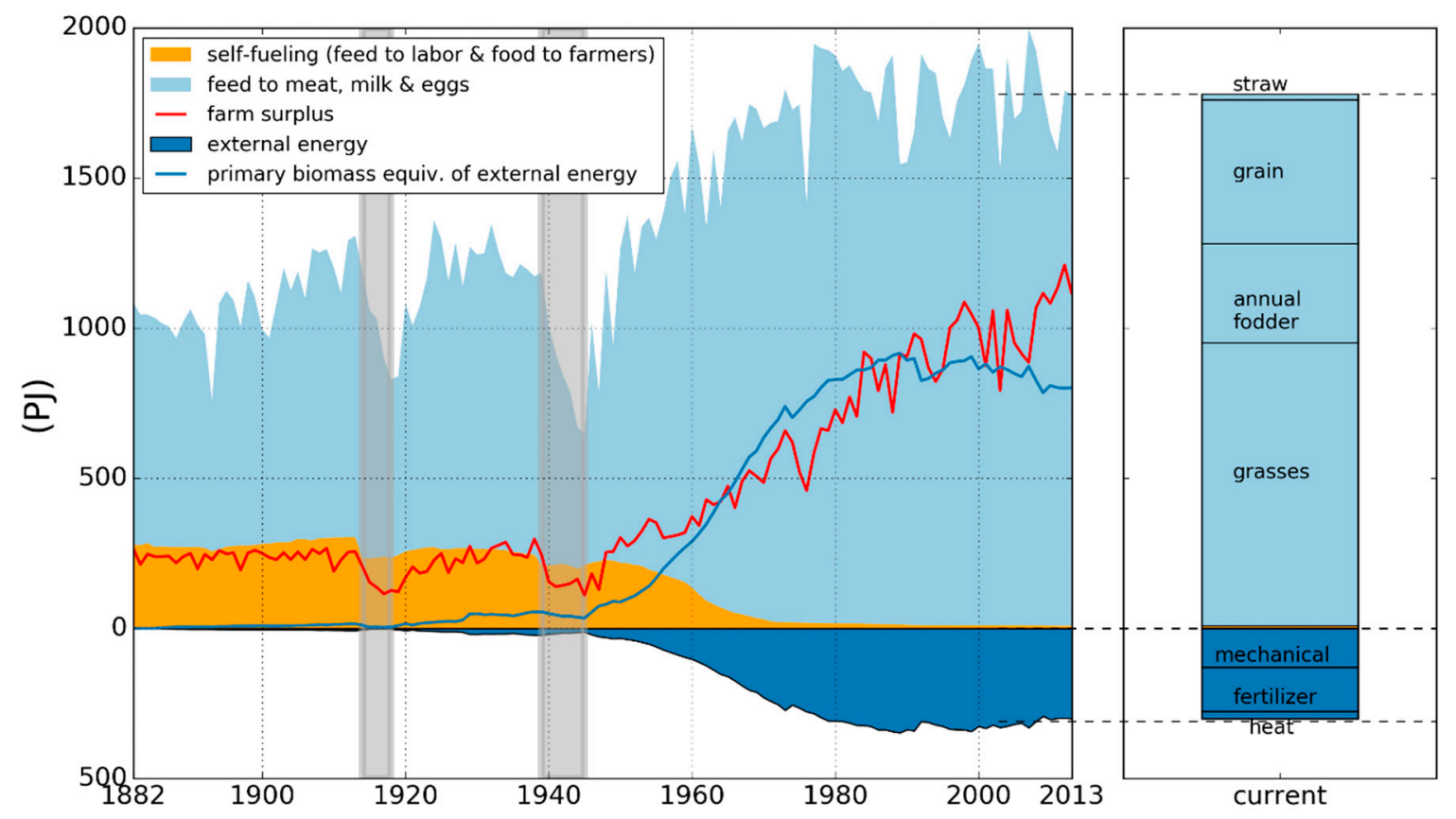

Figure 3. Feed for livestock production and self-fueling compared to farm surplus (upper figure), external energy (lower figure), and the primary biomass equivalent of external energy (upper figure) over time. The right end of the figure gives the composition of current feed among grasses, annual fodder, straw, and grain and the split of the external energy inputs among mechanical power, fertilizers, and heat.

Current energy inputs are dominated by fossil fuels for mechanical work and fertilizers (right panel). The strikingly high primary biomass equivalent of these inputs (blue line) highlights the difference in the free energy (i.e., the capacity to produce work) between fossil fuels and biomass. Since the early 1960s and until the early 1990s, the primary biomass equivalent of external inputs exceeded the farm surplus. The deficit maximized in the 1970s and diminished afterwards as driven by improvements in nitrogen use and combustion engine efficiencies [4]. Today the functional energy cost of industrial agriculture expressed in terms of primary biomass is equivalent to the farm surplus. Accordingly, it cancels out the energy produce of agriculture. The disruption of self-fueling freed up resources that got reallocated in the production of meat, milk, and eggs and not to energy any more. Current feed amounts to $1700 \mathrm{PJ}$ and puts a great burden on the energy metabolism of agriculture.

To achieve energy neutrality, agriculture would need to recover from internal sources the amount of energy represented by the blue line in Figure 3. The challenge is huge because the amount to recover 
is almost as high as the current farm surplus. This means that current agriculture would need to almost double its energy production in order to offset its dependency on fossil fuels without reducing its farm surplus.

\subsection{Energy Recovery Potential from Crop Residues and Manure}

Figure 4 shows the estimated energy content of all crop residues and livestock manure in France compared to current energy recovery and to two evaluations both considering the full recovery of the animal manure produced in confinement and respectively $30 \%$ and $70 \%$ of all energy in crop residues. The quantification provides the order of magnitude of the energy reserves in agricultural residues and highlights that energy neutrality from residues would at best be respectively $60 \%$ and $100 \%$.

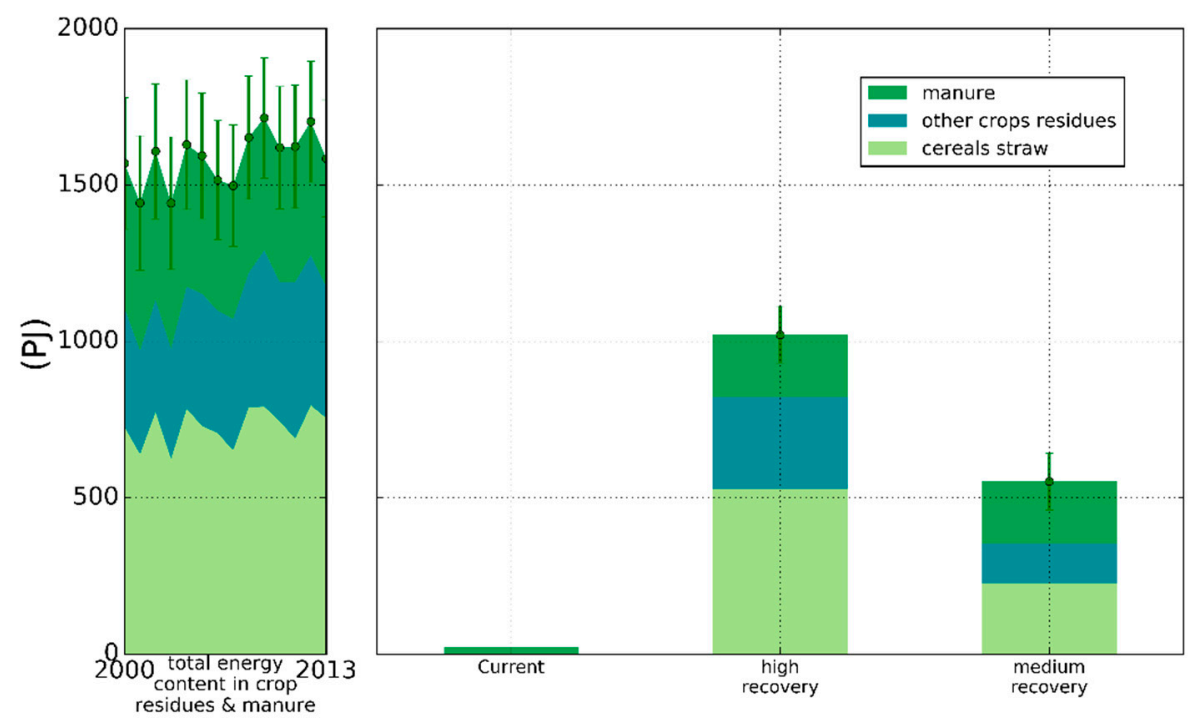

Figure 4. The energy content of crop residues and animal manure estimated for the period from 2000 to 2013 (left panel) compared to current energy recovery from these materials and to two potential recovery rates integrating uncertainty for manure excretion.

In 2016, total biogas production in France was about 30 PJ (in terms of oil equivalent), out of which only about one-fourth (7.8 PJ) originated from agriculture [52,53] (the rest is from organic materials from wastewater treatment plants, municipal waste and agri-food industries). Its primary biomass equivalent is $26 \mathrm{PJ}$ and adds to the $200 \mathrm{PJ}$ [53] of farm surplus currently allocated to liquid biofuels (see Supplementary Materials for detailed calculation). The remaining farm surplus of $880 \mathrm{PJ}$ is food. Accordingly, including the production of first-generation biofuels, current agriculture has an energy neutrality of about $25 \%$, very highly competing with food production. Energy neutrality and therefore, the capacity of agriculture to be a net energy source to society and massively displace fossil fuels without further reducing food production appears to be extremely challenging. Even with very high energy recovery from agricultural residues, additional recovery from internal sources is a necessary condition for producing energy neutrality and displacing fossil fuels. In the four energy neutrality scenarios, farm surplus is fully put aside for food production.

\subsection{Energy Neutrality Scenarios}

An option to recover more energy from internal sources and achieve energy neutrality is to reduce the livestock feed. Figure 5 puts in perspective the energy balances in the four scenarios of energy neutrality presented in Table 2 with the current energy budget of agriculture.

The results show that energy neutrality greatly affects the farm surplus. Only the scenarios combining both the suppression of feed grain and annual fodder and high energy recovery from agricultural residues allow an increase in farm surplus (S1b and S2b). The farm surplus increases by 
$25 \%$ and $60 \%$ in S1b and S2b respectively compared to today. S2b scenario provides an estimate of the maximum production capacity of renewable energy by French agriculture. In S2a, the farm surplus is equal to today. In scenario S1a, the farm surplus drops by $35 \%$ and gets closer to current domestic consumption, implying that far fewer international exports can be sustained.

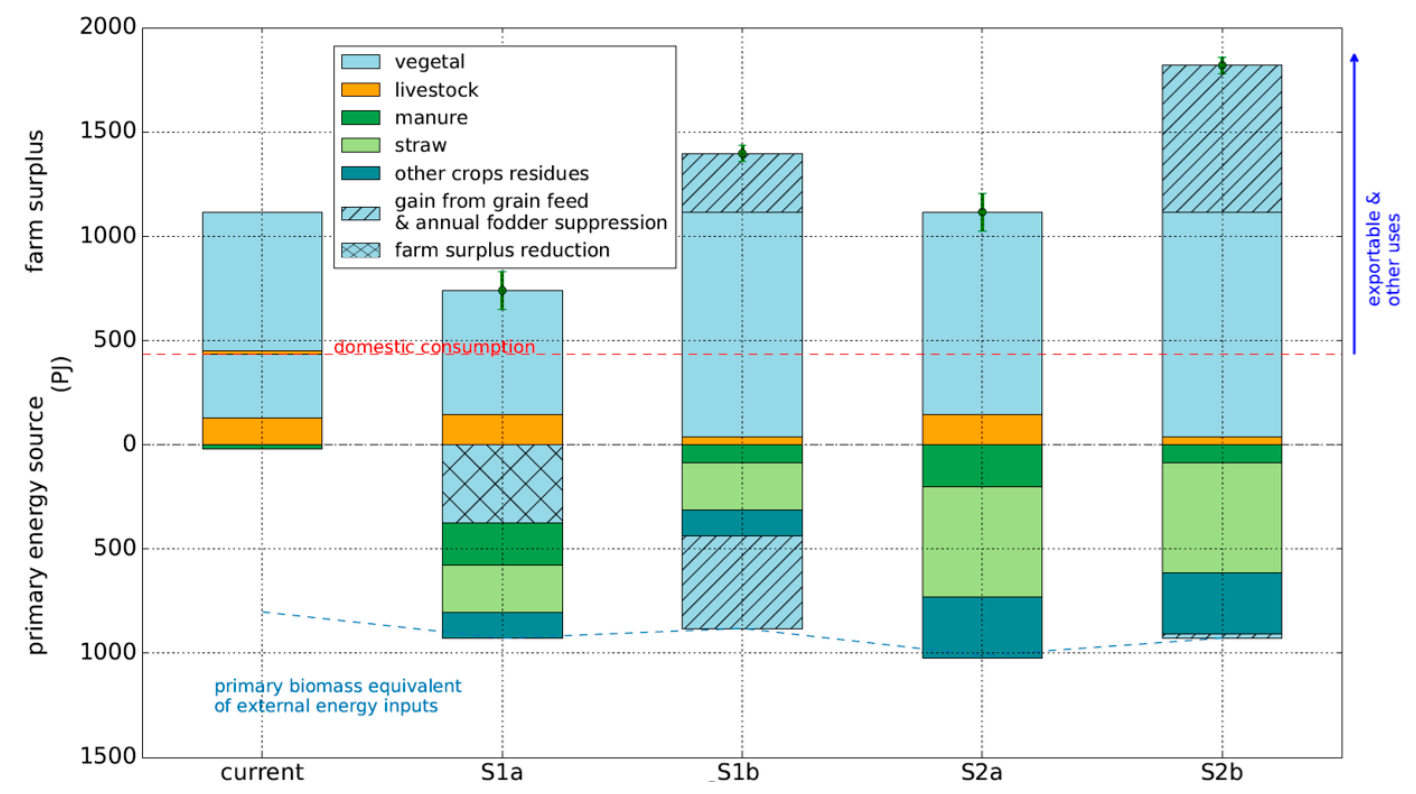

Figure 5. Farm surplus (vegetal and livestock) and the primary biomass equivalent of external energy per source for the four scenarios and by comparison to the current situation. Farm surplus is divided into domestic food requirement and potential food exports and other uses by the red dotted line.

The suppression of grain and annual fodder in scenarios S1b and S2b brings livestock production about 70\% down (from 150 to $45 \mathrm{PJ}$ ) and translates into slightly lower total energy requirements due to less energy consumption in livestock buildings compared to S1a and S2a. Virtually all livestock production in these scenarios is from cattle. In general, the suppression of grain feed and annual fodder appears to be an option with higher potential than the energy recovery from crop residues and manure.

\section{Discussion}

\subsection{Energy Recovery Potential and the Role of Livestock}

Our study assesses the challenges and consequences of reaching energy neutrality in French agriculture. The energy recovery potential is unlikely to increase as both crop residues and manure depend on agricultural yields, which have reached a plateau [4]. Overall, the estimated energy recovery potential is on the high end of previous assessments for France [33,54]. Uncertainty is essentially driven by the rate of recoverable straw. Low recovery rates are consistent with straw landfilling/return methods, which are part of today's major farm management practices for soil quality conservation and carbon sequestration [28]. In contrast, high recovery rates were common in pre-industrial systems witnessing for the central role of straw as an energy source [4,55]. Recovery rates closer to the high case are potentially compatible with sustainable soil management if the digestate is returned to the fields [56]. Future research is also required to analyze which straw recovery rate can balance the right energetic and environmental tradeoff in straw use [44]. Note that straw availability inversely depends on the harvest index of crops. A high harvest index favors grain production against crop residues. Accordingly, the energy recovery potential from straw decreased with agricultural industrialization. Concerning manure, our estimates vary between 108 and $291 \mathrm{PJ}$. The range is in agreement with a recent analysis [57] providing an estimate of $111 \mathrm{PJ}$ for cattle manure only, which represents about $75 \%$ 
of all recoverable manure, based on a detailed description of cattle production and type of housing and quality of bedding.

Overall, the energy balance in this study is very optimistic because it considers a full recovery of the manure energy produced in confinement [50]. In addition, the energy cost for the recovery of agricultural residues is most likely underestimated [51]. More generally, besides energy considerations, the recovery of agricultural residues would require structural changes in farm holdings, including the construction of storage capacities as well as a global system design approach to biogas plant infrastructures and distances to feedstock [56,58]. Current agricultural specialization between, on the one hand, regions with high livestock densities (e.g., Brittany) and, on the other hand, energy intensive crop monocultures (e.g., Centre) [59] implies a geographical dispersion of the two terms of the energy balance of agriculture.

For a given farm surplus, the share of biofuels compared to food remains a political decision. The current farm surplus includes first generation biofuels for around $18 \%$ (200 out of 1100 PJ) in terms of primary biomass [53]. Numerous changes have occurred in the European directives. Incentives for first generation biofuels appeared in 2003 targeting to supply the transportation sector. They got revised downwards through the Renewable Energy Directive (RED) in 2009 [56] following concerns on land use competition with food production. Incentives on first generation biofuels will most likely phase out in the revised RED II directive (2020-2030) in favor of advanced biofuels (second generation) mainly from crop residues and manure [60] which are at the core of the present study.

Re(acknowledging) feed as energy provides insights on how to value the resources from a global system perspective. Setting the grain and annual fodder used as feed to zero in S1b and S2b results in energy savings above $800 \mathrm{PJ}$ (Figure 5). Grain feed is constant at about $35 \%$ of all grain produced in France since 1961 [26,61], but this constant share hides the fivefold tonnage increase due to crop yields improvements. Today, livestock feed amounts to $1700 \mathrm{PJ}$ which is equivalent to the French domestic natural gas consumption [62]. Other countries have shown feed growth trends comparable to France $[63,64]$ highlighting that dietary choices become a highly relevant international component of the energy transition. The scenarios of feed grain suppression emphasize the role of feed in the full energy balance of agriculture but are very ambitious as they imply that poultry or pig productions would radically reduce to levels limited by food waste recovery as feed. A more realistic scenario would be an intermediate scenario with lower feed reduction, which, however, would also imply lower energy neutrality opportunities.

\subsection{Structural Dependencies on Fossil Fuels and Constraints in the Electrification of Agriculture}

The electrification of agriculture is way more challenging than for other sectors. Although agriculture can contribute in solar and wind-based electricity generation, the bulk of agricultural energy use is not supportable by electricity. Electricity use in agriculture has tripled since 1970 [65] to $9 \%$ today (Table 1) but further increase is limited to an upper limit estimated at $22 \%$ (deductible from Table 1). This limit corresponds to the full electrification of all current non-field energy uses including irrigation, greenhouses, and other equipment [66-68]. Synthetic nitrogen fertilizer production could theoretically also switch to electricity but the energy requirements for hydrogen production from water through electrolysis are $60 \%$ higher than the current production using natural gas [69]. Field works involve machinery with nominal power of several hundreds of $\mathrm{kW}$, which could only operate if plugged to the grid [70]. The transportation sector, which is the sector with similar horsepower engines, faces numerous unresolved issues in its electrification strategy except for the railway, which is powered by overhead lines. Still, efforts in electrification of agriculture should be encouraged but the penetration of electricity to field work machines would require heavy changes in agricultural structures, potentially involving a reduction in farm sizes, a downscale in the power of machinery and subsequent increases in the number of machines and farmers. 


\subsection{Current Energy Efficiency in Agriculture Already at Maximum}

A common indicator for capturing the viability of energy systems is the energy return on energy invested (EROI) [71]. For agriculture, the EROI is the ratio of energy return from biomass production to total energy invested from internal and external sources. There is no standard approach for agricultural EROI calculation, especially because of methodological discrepancies concerning the energy invested [4]. A major discrepancy concerns system boundaries. It is essential to include both direct and indirect energy use in the calculation of both EROI and energy neutrality. The exclusion of indirect energy would of course lead to a misleadingly high balance between agricultural energy production and consumption. In the EROI analysis of agriculture in France, Harchaoui and Chatzimpiros [4] demonstrated a doubling of EROI from two to four during industrialization owing to efficiency improvements in motors and in the use of fertilizers. These two variables are the main drivers of total energy efficiency in agriculture and have already reached or are close to a plateau [4]. This means that the energy consumption per unit of production cannot be reduced significantly. Currently, energy inputs are dominated by fossil fuels. Their high energy density and readiness in nature implies that their replacement by bioenergy would translate into much higher primary energy inputs and so into lower EROI. The EROI of energy neutral agriculture is the sum of farm surplus plus the recovered energy from agricultural residues to the primary biomass equivalent of the energy invested. Our scenarios demonstrate that the EROI of energy-neutral agriculture ranges from about 1.8 (in S1a) and 2.8 (in S2b) which is quite close to the EROI of preindustrial self-sufficient agriculture [4]. The energy neutrality framework could prove to be a useful tool for consistently assessing prospective scenarios integrating food and other energy [72].

Beyond marginal technical efficiency gains that can still be achieved in livestock buildings and greenhouses, potential energy savings could be found in conservation practices. Zero or minimum tillage techniques could translate into lower field work requirements and are already in place on $35 \%$ of the major crops area in France [53]. Their further expansion may be a promising path for improving the energy balance of agriculture, providing that they do not compromise crop productivity [73]. The latest national low-carbon strategy plan sets a 35\% reduction target to the direct energy consumption of agriculture by 2030 compared to 2010 [74]. Such a reduction could only result from conservation practices, feed use decrease, or food waste reduction, considering that today the per capita daily food supply in France is of $3480 \mathrm{kcal}$, against a recommended caloric intake of $2200 \mathrm{kcal}$ [26,75].

\section{Conclusions}

This paper examines the energy balance of agriculture by accounting for internal and external energy sources on a comparable basis. Due to the overwhelming dependence of agriculture on external energy sources, dominated by fossil fuels, reaching energy neutrality is extremely challenging. Agriculture is locked in fossil fuels and a transition to electricity is largely constrained by the nature of agricultural machinery. Our results highlight that the major opportunity to reach energy neutrality in agriculture is in feed reduction. Energy neutrality is a prerequisite for agriculture to be a net energy source to society.

Beyond the numerical results for France, this paper provides a generic framework for assessing net energy balances in agriculture. The links between energy and agriculture have often been overseen and transition policies in the sectors of energy, transport, and agriculture fail to adopt transversal approaches. The framework of this paper can provide insights to civil society and policy makers on the energy limits and opportunities of agriculture according to production practices and the farm surplus composition. Any analysis of the potential displacement of fossil fuels by agriculture must build on a full and consistent energy balance putting production and the functional requirements of agriculture into common comparable perspective. 
Supplementary Materials: The following are available online at http:/ /www.mdpi.com/2071-1050/10/12/4624/ s1. The supporting information provides additional details on the energy conversion efficiency calculation of biomass to fuel.

Author Contributions: Both authors developed, discussed and co-wrote the article.

Funding: The work built on funds of the research program Emergence Ville de Paris Convention 2015 DDEES 165.

Acknowledgments: The authors thank four anonymous reviewers and the editor for their useful comments and suggestions for improving the manuscript.

Conflicts of Interest: The authors declare no conflict of interest.

\section{References}

1. Smil, V. Energy and Civilization: A History; The MIT Press: Cambridge, MA, USA; London, UK, 2017; ISBN 978-0-262-03577-4.

2. Arizpe, N.; Giampietro, M.; Ramos-Martin, J. Food Security and Fossil Energy Dependence: An International Comparison of the Use of Fossil Energy in Agriculture (1991-2003). Crit. Rev. Plant Sci. 2011, 30, 45-63. [CrossRef]

3. Pelletier, N.; Audsley, E.; Brodt, S.; Garnett, T.; Henriksson, P.; Kendall, A.; Kramer, K.J.; Murphy, D.; Nemecek, T.; Troell, M. Energy Intensity of Agriculture and Food Systems. Ann. Rev. Environ. Resour. 2011, 36, 223-246. [CrossRef]

4. Harchaoui, S.; Chatzimpiros, P. Energy, Nitrogen, and Farm Surplus Transitions in Agriculture from Historical Data Modeling. France, 1882-2013. J. Ind. Ecol. 2018. [CrossRef]

5. Odum, H. Energetics of world food production. In The World Food Problem, Report of the President's Science Advisory Committee, Panel on World Food Supply; The White House: Washington, DC, USA, 1967; Volume 3, pp. 55-94.

6. Energy and Agreicultur; Advanced Series in Agricultural Sciences; Stanhill, G., Ed.; Springer: Berlin/Heidelberg, Germany, 1984; ISBN 978-3-540-13476-3.

7. Pimentel, D.; Pimentel, M. Food, Energy, and Society, 3rd ed.; CRC Press: Boca Raton, FL, USA, 2008; ISBN 978-1-4200-4667-0.

8. Woods, J.; Williams, A.; Hughes, J.K.; Black, M.; Murphy, R. Energy and the food system. Philos. Trans. R. Soc. B Biol. Sci. 2010, 365, 2991-3006. [CrossRef] [PubMed]

9. Galán, E.; Padró, R.; Marco, I.; Tello, E.; Cunfer, G.; Guzmán, G.I.; González de Molina, M.; Krausmann, F.; Gingrich, S.; Sacristán, V.; et al. Widening the analysis of Energy Return on Investment (EROI) in agro-ecosystems: Socio-ecological transitions to industrialized farm systems (the Vallès County, Catalonia, c.1860 and 1999). Ecol. Model. 2016, 336, 13-25. [CrossRef]

10. Pimentel, D.; Hurd, L.E.; Bellotti, A.C.; Forster, M.J.; Oka, I.N.; Sholes, O.D.; Whitman, R.J. Food Production and the Energy Crisis. Science 1973, 182, 443-449. [CrossRef] [PubMed]

11. Haberl, H. The Energetic Metabolism of Societies: Part II: Empirical Examples. J. Ind. Ecol. 2001, 5, 71-88. [CrossRef]

12. Haberl, H.; Erb, K.-H.; Krausmann, F.; Bondeau, A.; Lauk, C.; Müller, C.; Plutzar, C.; Steinberger, J.K. Global bioenergy potentials from agricultural land in 2050: Sensitivity to climate change, diets and yields. Biomass Bioenergy 2011, 35, 4753-4769. [CrossRef]

13. Gerbens-Leenes, P.W.; Mekonnen, M.M.; Hoekstra, A.Y. The water footprint of poultry, pork and beef: A comparative study in different countries and production systems. Water Resour. Ind. 2013, 1-2, 25-36. [CrossRef]

14. Miglietta, P.P.; Giove, S.; Toma, P. An optimization framework for supporting decision making in biodiesel feedstock imports: Water footprint vs. import costs. Ecol. Indic. 2018, 85, 1231-1238. [CrossRef]

15. Galloway, J.N.; Winiwarter, W.; Leip, A.; Leach, A.M.; Bleeker, A.; Erisman, J.W. Nitrogen footprints: Past, present and future. Environ. Res. Lett. 2014, 9, 115003. [CrossRef]

16. Zhuang, Y.; Zhang, H.; Wang, X.; Fang, J. Evolution of Sustainable Carbon Cycling Processes in China. Chin. J. Popul. Resour. Environ. 2004, 2, 4-10.

17. Odum, H.T. Energy, Ecology, and Economics. Ambio 1973, 2, 220-227. 
18. Smith, P.; Martino, D.; Cai, Z.; Gwary, D.; Janzen, H.; Kumar, P.; McCarl, B.; Ogle, S.; O’Mara, F.; Rice, C.; et al. Greenhouse gas mitigation in agriculture. Philos. Trans. R. Soc. B Biol. Sci. 2008, 363, 789-813. [CrossRef] [PubMed]

19. FAO. Energy-Smart Food for People and Climate; Issue Paper; Food and Agriculture Organization of the United Nations-Issue Paper; The Food and Agriculture Organization of the United Nations: Rome, Italy, 2011.

20. Canning, P.; Rehkamp, S.; Waters, A.; Etemadnia, H. The Role of Fossil Fuels in the U.S. Food System and the American Diet; ERR-224; U.S. Department of Agriculture: Washington, DC, USA, 2017; p. 97.

21. Sachs, I.; Silk, D. Food and Energy: Strategies for Sustainable Development; United Nations University Press: Tokyo, Japan, 1990; ISBN 978-92-808-0757-8.

22. Halberg, N.; Dalgaard, R.; Olesen, J.E.; Dalgaard, T. Energy self-reliance, net-energy production and GHG emissions in Danish organic cash crop farms. Renew. Agric. Food Syst. 2008, 23, 30-37. [CrossRef]

23. Pimentel, D.; Patzek, T.W. Ethanol Production Using Corn, Switchgrass, and Wood; Biodiesel Production Using Soybean and Sunflower. Nat. Resour. Res. 2005, 14, 65-76. [CrossRef]

24. Markussen, M.V.; Pugesgaard, S.; Oleskowicz-Popiel, P.; Schmidt, J.E.; Østergård, H. Net-Energy Analysis of Integrated Food and Bioenergy Systems Exemplified by a Model of a Self-Sufficient System of Dairy Farms. Front. Energy Res. 2015, 3. [CrossRef]

25. Krausmann, F. Milk, Manure, and Muscle Power. Livestock and the Transformation of Preindustrial Agriculture in Central Europe. Hum. Ecol. 2004, 32, 735-772. [CrossRef]

26. FAOSTAT. FAO Statistical Database; The Food and Agriculture Organization of the United Nations: Rome, Italy, 2018.

27. Foley, J.A.; Ramankutty, N.; Brauman, K.A.; Cassidy, E.S.; Gerber, J.S.; Johnston, M.; Mueller, N.D.; O'Connell, C.; Ray, D.K.; West, P.C.; et al. Solutions for a cultivated planet. Nature 2011, 478, 337-342. [CrossRef]

28. Smil, V. Crop Residues: Agriculture's Largest Harvest. BioScience 1999, 49, 299-308. [CrossRef]

29. Harchaoui, S.; Chatzimpiros, P. Reconstructing production efficiency, land use and trade for livestock systems in historical perspective. The case of France, 1961-2010. Land Use Policy 2017, 67, 378-386. [CrossRef]

30. Agreste Les exploitations agricoles consomment majoritairement des produits pétroliers. Agreste $2014,311$.

31. Huang, W.-D.; Zhang, Y.-H.P. Energy Efficiency Analysis: Biomass-to-Wheel Efficiency Related with Biofuels Production, Fuel Distribution, and Powertrain Systems. PLoS ONE 2011, 6, e22113. [CrossRef] [PubMed]

32. McKendry, P. Energy production from biomass (part 2): Conversion technologies. Bioresour. Technol. 2002, 83, 47-54. [CrossRef]

33. Ademe. Estimation des gisements potentiels de substrats utilisables en méthanisation; Ademe; Agence de l'Environnement et de la Maîtrise de l'Energie: Angers, France, 2013; p. 117.

34. Nutrient Requirements of Dairy Cattle, 7th ed.; National Research, Council (Ed.) Nutrient Requirements of Domestic Animals; National Academy Press: Washington, DC, USA, 2001; ISBN 978-0-309-06997-7.

35. Ministère de la Transition Ecologique et Solidaire Transport Revue Transport; Cerema, Centre d'études et d'expertise sur les risques, l'environnement, la mobilité et l'aménagement: Provins, France, 2014.

36. MAN Diesel \& Turbo Two-stroke Low Speed Diesel Engines; MAN Diesel \& Turbo: Copenhagen, Denmark, 2013; p. 20.

37. Smil, V. Energy in Nature and Society: General Energetics of Complex Systems; MIT Press: Cambridge, MA, USA, 2008; ISBN 978-0-262-19565-2.

38. Hakawati, R.; Smyth, B.M.; McCullough, G.; De Rosa, F.; Rooney, D. What is the most energy efficient route for biogas utilization: Heat, electricity or transport? Appl. Energy 2017, 206, 1076-1087. [CrossRef]

39. Smil, V. Enriching the Earth: Fritz Haber, Carl Bosch, and the Transformation of World Food Production; MIT: Cambridge, MA, USA; London, UK, 2001; ISBN 978-0-262-69313-4.

40. Agreste. L'artificialisation des Terres de 2006 à 2014: Pour Deux Tiers sur des Espaces Agricoles; Agreste-La Statistique Agricole: Montreuil-sous-Bois, France, 2015.

41. Grassland Productivity and Ecosystem Services; Lemaire, G.; Hodgson, J.; Chabbi, A. (Eds.) CABI: Wallingford, UK, 2011; ISBN 978-1-84593-809-3.

42. Chatzimpiros, P. Les empreintes environnementales de l'approvisionnement alimentaire: Paris ses viandes et lait XIXème—XXIème siècles. Thèse de doctorat, Université Paris-Est, Champs-sur-Marne, France, 2011. (in French). 
43. Gerbens-Leenes, P.W.; Nonhebel, S. Critical water requirements for food, methodology and policy consequences for food security. Food Policy 2004, 29, 547-564. [CrossRef]

44. Monteleone, M.; Cammerino, A.R.B.; Garofalo, P.; Delivand, M.K. Straw-to-soil or straw-to-energy? An optimal trade off in a long term sustainability perspective. Appl. Energy 2015, 154, 891-899. [CrossRef]

45. Smil, V. Nitrogen in crop production: An account of global flows. Glob. Biogeochem. Cycles 1999, 13, 647-662. [CrossRef]

46. Smil, V. Feeding the World: A Challenge for the Twenty-First Century; MIT Press: Cambridge, MA, USA; London, UK, 2000; ISBN 978-0-262-19432-7.

47. Ferrell, C.L.; Oltjen, J.W. ASAS CENTENNIAL PAPER: Net energy systems for beef cattle-Concepts, application, and future models1. J. Anim. Sci. 2008, 86, 2779-2794. [CrossRef]

48. Velayudhan, D.E.; Kim, I.H.; Nyachoti, C.M. Characterization of Dietary Energy in Swine Feed and Feed Ingredients: A Review of Recent Research Results. Asian-Aust. J. Anim. Sci. 2014, 28, 1-13. [CrossRef]

49. INRA INRA-CIRAD-AFZ Feed Tables. Available online: https://feedtables.com/fr (accessed on 26 October 2018).

50. Giuntoli, J.; Boulamanti, A.K.; Corrado, S.; Motegh, M.; Agostini, A.; Baxter, D. Environmental impacts of future bioenergy pathways: The case of electricity from wheat straw bales and pellets. GCB Bioenergy 2013, 5, 497-512. [CrossRef]

51. Börjesson, P.; Berglund, M. Environmental systems analysis of biogas systems-Part I: Fuel-cycle emissions. Biomass Bioenergy 2006, 30, 469-485. [CrossRef]

52. Ademe, I Care \& Consult, Blézat Consulting, CERFrance, Céréopa. Agriculture et énergies Renouvelables: état de l'art et Opportunités pour les Exploitations Agricoles; Agence de l'Environnement et de la Maîtrise de l'Energie: Angers, France, 2017; p. 70.

53. CGDD; Environnement \& Agriculture. Chiffres Clés des énergies Renouvelables, 2018th ed.; Commissariat Général au Développement Durable: La Défense, France, 2018.

54. Meyer, A.K.P.; Ehimen, E.A.; Holm-Nielsen, J.B. Future European biogas: Animal manure, straw and grass potentials for a sustainable European biogas production. Biomass Bioenergy 2018, 111, 154-164. [CrossRef]

55. Toutain, J.-C. Le produit de l'agriculture Française de 1700 à 1958; Cahiers de l'Institut de Science Economique Appliquee: Paris, France, 1958.

56. Einarsson, R.; Persson, U.M. Analyzing key constraints to biogas production from crop residues and manure in the EU-A spatially explicit model. PLoS ONE 2017, 12, e0171001. [CrossRef] [PubMed]

57. Degueurce, A.; Capdeville, J.; Perrot, C.; Bioteau, T.; Martinez, J.; Peu, P. Cattle manure as a resource for biogas conversion in France? Sci. Eaux Territ. 2016, 24, 1-9.

58. Scheftelowitz, M.; Thrän, D. Unlocking the Energy Potential of Manure-An Assessment of the Biogas Production Potential at the Farm Level in Germany. Agriculture 2016, 6, 20. [CrossRef]

59. Le Noë, J.; Billen, G.; Garnier, J. How the structure of agro-food systems shapes nitrogen, phosphorus, and carbon fluxes: The generalized representation of agro-food system applied at the regional scale in France. Sci. Total Environ. 2017, 586, 42-55. [CrossRef] [PubMed]

60. European Union Proposal of a Directive Of the European Parliament and the Council on the Promotion of the Use of Energy from Renewable Sources (recast)EUR-Lex-52016PC0767R(01)-EN-EUR-Lex. Available online: https:/ / eur-lex.europa.eu/legal-content/EN/TXT/?uri=CELEX:52016PC0767R\%2801\%29 (accessed on 17 September 2018).

61. Agreste. L'Alimentation Animale, Principale Destination des Productions Végétales; Collection Agreste Primeur; Agreste-La Statistique Agricole: Montreuil-sous-Bois, France, 2013.

62. SOES. Le bilan du gaz Naturel en France en 2015; Service de l'observation et des statistiques; Commissariat Général au Développement Durable: La Défense, France, 2017.

63. Guzmán, G.I.; González de Molina, M.; Soto Fernández, D.; Infante-Amate, J.; Aguilera, E. Spanish agriculture from 1900 to 2008: A long-term perspective on agroecosystem energy from an agroecological approach. Reg. Environ. Change 2018, 18, 995-1008. [CrossRef]

64. Thornton, P.K. Livestock production: Recent trends, future prospects. Philos. Trans. R. Soc. B Biol. Sci. 2010, 365, 2853-2867. [CrossRef]

65. SOES. Bilan énergétique de la France 2014; Service de l'observation et des statistiques; Commissariat Général au Développement Durable: La Défense, France, 2015. 
66. Chen, C.; Ling, H.; Zhai, Z.; Li, Y.; Yang, F.; Han, F.; Wei, S. Thermal performance of an active-passive ventilation wall with phase change material in solar greenhouses. Appl. Energy 2018, 216, 602-612. [CrossRef]

67. Ozgener, O. Use of solar assisted geothermal heat pump and small wind turbine systems for heating agricultural and residential buildings. Energy 2010, 35, 262-268. [CrossRef]

68. Hartung, H.; Pluschke, L. The Benefits and Risks of Solar Powered Irrigation-A Global Overview; FAO: Rome, Italy, 2018.

69. Pimentel, D.; Whitecraft, M.; Scott, Z.R.; Zhao, L.; Satkiewicz, P.; Scott, T.J.; Phillips, J.; Szimak, D.; Singh, G.; Gonzalez, D.O.; et al. Will Limited Land, Water, and Energy Control Human Population Numbers in the Future? Hum. Ecol. 2010, 38, 599-611. [CrossRef]

70. Moreda, G.P.; Muñoz-García, M.A.; Barreiro, P. High voltage electrification of tractor and agricultural machinery-A review. Energy Convers. Manag. 2016, 115, 117-131. [CrossRef]

71. Hamilton, A.; Balogh, S.; Maxwell, A.; Hall, C. Efficiency of Edible Agriculture in Canada and the U.S. Over the Past Three and Four Decades. Energies 2013, 6, 1764-1793. [CrossRef]

72. Solagro. Le scénario Afterres2050 Version 2016; Solagro: Toulouse, France, 2016.

73. Pittelkow, C.M.; Linquist, B.A.; Lundy, M.E.; Liang, X.; van Groenigen, K.J.; Lee, J.; van Gestel, N.; Six, J.; Venterea, R.T.; van Kessel, C. When does no-till yield more? A global meta-analysis. Field Crops Res. 2015, 183, 156-168. [CrossRef]

74. MEDDE. France National Low-Carbon Strategy; Ministère de L'écologie, du Développement Durable et de L'énergie: La Défense, Franc, 2015.

75. Joint FAO/WHO/UNU Expert Consultation on Protein and Amino Acid Requirements in Human Nutrition (2002: Geneva, Switzerland); Food and Agriculture Organization of the United Nations; World Health Organization; United Nations University. Protein and Amino Acid Requirements in Human Nutrition: Report of a Joint FAO/WHO/UNU Expert Consultation; WHO Technical Report Series; World Health Organization: Geneva, Switzerland, 2007; Volume 935.

(C) 2018 by the authors. Licensee MDPI, Basel, Switzerland. This article is an open access article distributed under the terms and conditions of the Creative Commons Attribution (CC BY) license (http:// creativecommons.org/licenses/by/4.0/). 